\title{
ПЕРИФРАЗ І ЙОГО ТЕКСТОТВІРНІ ФУНКЦІЇ В КОТЛЯРЕВСЬКОЗНАВЧОМУ ДИСКУРСІ ОЛЕСЯ ГОНЧАРА
}

\author{
Котляревський був першим полоненим \\ української народної культури... \\ Свген Сверстюк
}

\begin{abstract}
У дослідженні різнобічно схарактеризовано перифрастичний потенціал літературознавчої статті “Безсмертний полтавець” Олеся Гончара: 1) вичленувано перифрастичні поля «Іван Котляревський», “"Енеїда” Івана Котляревського», «"Наталка Полтавка” Івана Котляревського», " “Москаль-чарівник” Івана Котляревського»; 2) ідентифіковано компонентний склад аналізованих полів; 3) з ясовано текстотвірні функції описових й образно-переносних найменувань антропоніма Іван Котляревський, бібліонімів «Енеїда», «Наталка Полтавка», «Москаль-чарівник»; 4) установлено родо-видові й синонімічні залежності між описуваними вторинними номінуваннями.
\end{abstract}

Ключові слова: стаття Олеся Гончара «Безсмертний полтавець»; перифраз; образно-описові найменування; антропонім Іван Котляревський; бібліоніми «Енеїда», «Наталка Полтавка», «Москаль-чарівник»; перифрастичне поле; перифрастична парадигма.

Stepanenko M.I. Periphrasis and Its Textural Functions in Oles Honchar's Kotliarevskyi Discourse. The article reviews the periphrastic potential of the particular discourse - Oles Honchar's literary article "The Immortal Poltavite" The facts mentioned in O. Honchar's work give grounds to assert that the descriptive structures based on identifying semes are united into separate paradigmatic fields, the main ones being as follows: 'Ivan Kotliarevsky', “'Eneyida' by Ivan Kotliarevsky”, “'Natalka Poltavka' (Natalka from Poltava) by Ivan Kotliarevsky”, “'Moskal Charivnyk' (The Muscovite Sorcerer) by Ivan Kotliarevsky". The narrow semantic groups can be defined as peripheral paradigms. The study has singled out these paradigms and their component structure. The anthroponym 'Ivan Kotliarevsky' and the biblionym 'Eneyida' have the most extended paradigmatic formations. As for the degree of emotional constituents, the secondary nominations can be differentiated as descriptive constructions and figurative nominations. The former relates to anthroponym 'Ivan Kotliarevsky', and his specific authorship in particular. It has been proved that the main purpose of these periphrases is to avoid the repetition of the anthroponym 'Ivan Kotliarevsky' in short texts. The research has revealed the nuclear formations among the figurative nominations, i.e. the ones that convey the highest degree of evaluation. They refer to general constructions such as the "founder of the new Ukrainian literature", "the first representative of the Ukrainian classic literature", and the individual author-described syntactical structures, such as the "cheerful life-loving genius", "the true son of Ukraine". The author has analyzed the figurative potential of the periphrases and used the method of component analysis, and the elements of the semasiological evaluation. This made it possible to interpret the textural functions of descriptive constructions and figurative nominations of the anthroponym 'Ivan Kotliarevsky', and biblionyms 'Eneyida', 'Natalka Poltavka', 'Moskal Charivnyk' in different ways. This article has defined the generic hyponym-hyperonym and synonymic relationships between the described secondary nominations. The first type of relationship relates to biblionyms, the second one deals with the anthroponyms and biblionyms. The research has proved the periphrasis to be an important source that reveals the significance Ivan Kotliarevsky's personality in the history of either Ukrainian or world literature and culture.

Key words: Oles Honchar's article "The Immortal Poltavite"; periphrasis; image-descriptive nominations; anthroponym 'Ivan Kotliarevsky'; biblionyms 'Eneyida', 'Natalka Poltavka', 'Moskal Charivnyk'; periphrastic field; periphrastic paradigm. 


\section{Вступ}

Олесь Гончар є не лише видатним прозаїком, а й талановитим літературознавцем, перу якого належать численні розвідки про майстрів художнього слова, культурних діячів. Високу оцінку одержали його літературно-критичні праці, шо ввійшли до книг «Про наше письменство» (К., 1972), «О тех, кто дорог» (М., 1978), «Письменницькі роздуми» (К., 1980). На особливу увагу заслуговує стаття «Безсмертний полтавець», в основу якої покладено доповідь на урочистому вечорі в Москві у Великому театрі, присвячену 200-річчю від дня народження Івана Котляревського. Ця праця - зразок блискучого літературознавчого аналізу місця й ролі конкретного письменника в історії української і світової літератури та культури. Вона вперше була надрукована в «Литературной газете» (1969. 10 вересня), «Літературній Україні» (1969. 16 вересня), згодом у виданнях «Про наше письменство», «О тех, кто дорог», «Письменницькі роздуми».

Студія, про яку мовиться, багата на художні засоби. 3-поміж них виняткове місце відведено перифразам. Мета пропонованої роботи - характеристика перифрастичного потенціалу статті «Безсмертний полтавець», зокрема, з'ясування текстотвірних функцій вторинних назв антропоніма Іван Котляревський та бібліонімів «Енеїда», «Наталка Полтавка», «Москаль-чарівник».

Проблеми перифрастики постійно привертали увагу лінгвістів (праці С. Срмоленко, I. Кобилянського, М. Коломійця, Є. Макаренко, А. Мойсієнка, Ю. Прадіда, Є. Регушевського, І. Соколової, Н. Сологуб та ін.). Нині особливої актуальності набуває з'ясування текстотвірної функції описових зворотів у структурі не лише художнього, а й наукового та публіцистичного дискурсів. Окремим аспектам цього важливого питання присвячені роботи І. Беркещук, Г. Євсєєвої, Л. Завгородньої, О. Копусь, М. Навальної, Ю. Макарець, І. Федькової та ін.

\section{Результати та дискусії}

Серед вторинних номінувань, що формують перифрастичне поле «Іван Котляревський», ядерну позицію займають усталені перифрази зачинатель нової української літератури і перший украӥнський класик: Радісно бачити, як широко святкує країна 200-річчя від дня народження зачинателя нової украӥнської літератури (Гончар, 1980: 18); Периого украӥнського класика вшановують сьогодні братні народи нашої <...> Вітчизни, дату народження Котляревського - за ухвалою ЮНЕСКО - відзначають у всьому світі (там само). Ядерність їх зумовлена, по-перше, індивідуальністю, тобто закріпленістю лише за одним антропонімом, і глибиною закладеного в них змісту. Про цю індивідуальність і цей зміст ідеться в самій статті Олеся Гончара: «Котляревський <...> почав писати з “красного рядка”, з нової сторінки; його мова це явище вже нової літератури, це <...> новий силабо-тонічний вірш, який так прегарно підкреслив можливості української мови, іiї милозвучність» (Гончар, 1980: 23).

Івана Котляревського вважають не лише зачинателем нової української літератури, а й зачинателем нової української літературної мови. Між цими 
описовими зворотами існує нерозривний зв'язок, власне, вони постають як дві вторинні назви одного феномена - Котляревського як першотворця нової української літератури й нової української літературної мови. У досліджуваному дискурсі не виявлено перифрази, що характеризувала білінгвотворчість письменника, однак потенційно-мотиваційна основа іiї чітко експлікована: «Завдяки Котляревському народна мова вперше стала мовою літератури. Слово, що від нього часом поспішали й відцуратися, пролунало з вуст Котляревського і дужо, й гідно. В “Енеїді" й “Наталці Полтавці" виразно можна було побачити, як починає формуватися українське красне письменство, як з незліченних джерелець народжується багатюща поетична мова України, майбутній Дніпро ії співучого й сяйного слова! У Котляревського сучасна наша літературна мова вже відчутно проступає в своїх основних рисах і властивостях, хоч потім ще багато належить зробити і на цій ниві Тарасові Шевченку, Іванові Франку, Лесі Українці, Коцюбинському, Тичині, Рильському, Остапу Вишні, Яновському та іншим письменникам» (Гончар, 1980: 27). Проступає не лише літературна мова в її невичерпності й зорієнтованості на весь українськомовний простір, не лише ії чіткі норми, що стосуються різних рівнів, а й досконалий правописний кодекс, вибазуваний на фонетичній основі, та оригінальний лексикографічний досвід.

Індивідуальність, яка властива щойно проаналізованим описовим структурам, корелює в сучасній українській мові хіба що з такими вторинними назвами, як основоположник нової української літератури, основоположннк нової української літературної мови. Ідеться, зрозуміло, про Тараса Шевченка, який поіменував свого великого попередника - Івана Котляревського - батьком. Про це також сказано в статті «Безсмертний полтавець» Олеся Гончара: «1838 року, коли Полтава прощалася з Котляревським, Шевченко у віршах, присвячених його пам'яті, назвав Котляревського батьком:

Будеш, батьку, панувати,

Поки живуть люди;

Поки сонце з неба сяє,

Тебе не забудуть!» (Гончар, 1980:27).

«Цим поетичним образом, - уточнює Олесь Терентійович, - визначено місце Котляревського в українській культурі» (там само).

Щодо перифрази перший український класик (Гончар, 1980:18), то вона за змістом уподібнена щойно проаналізованим описовим виразам і водночас протистоїть узвичаєному вторинному найменуванню останній класик старої української літератури, яка стосується іншого антропоніма - Григорій Сковорода. До речі, про це також уміщено розгорнуту інформацію в розглядуваному дискурсі: «У Котляревського були попередники. Був Іван Вишенський, пристрасний полеміст-сатирик, був знаменитий філософ Григорій Сковорода зі своїми мудрими піснями-кантами. До попередників $<\ldots>$ можна віднести й тих безіменних дяків-бакалярів, мандрівних бурсаків, неспокійних інтелектуалів своєї доби, що створили цілу сатиричну літературу, яка поширювалася в рукописних копіях, створили вертепну драму, дотепні 
пародії на біблійні сюжети, - духовний процес епохи, що передувала “Енеїді”, був позначений неабиякою активністю» (Гончар, 1980: 23).

Поряд із тільки-но схарактеризованими одиницями перифрастичного поля «Іван Котляревський» функціюють описові структури інших семантичних груп. Це, зокрема, перифрази-катойконіми, у яких роль конструктивного центру виконує іменник полтавець, що детермінує прикметники зі значенням внутрішнього емоційного стану людини (веселий), видільної (славний) і темпоральної (безсмертний) семантики: ...веселий полтавець не чужий в колі освічених, демократично настроєних людей своєї епохи... (Гончар, 1980: 20); І ие аж ніяк не применшує індивідуальності письменника, а злитість його вдачі з характером народу радше підносить славного полтавия перед нашим духовним зором (Гончар, 1980: 19); 3 нашої космічної ери видивляємося ми в цей віддалений від нас образ безсмертного полтавия... (Гончар, 1980: 27). До речі, останнє вторинне номінування слугує заголовком досліджуваної статті. Присубстантивні ад'єктиви виконують роль змістової домінанти, тобто постають як своєрідні ономасіологічні маркери, які «потенційно здатні робити денотат особистісно важливим для адресата», впливати «на формування ставлення до нього» (Макарець, 2012: 157). У відношенні семантичної сумісності з перифразом безсмертний полтавець перебуває описовий зворот, що має будову складного речення з присубстантивно-атрибутивною підрядною частиною ускладненого типу, довгожитель планети, який разом із витворами свого духу переступає грані сторіч, далеко йде за межі відміряного йому часу (Гончар, 1980: 18). Експліцитну значеннєву спорідненість у порівнюваних антропонімних описових зворотах виявляють такі компоненти, як безсмертний, довгожитель, сторіччя. Їхнє основне текстове призначення актуалізація семи 'який назавжди залишиться в пам'яті людей'.

Найпоширеніший різновид становлять логічні перифрази, що передають зневиразнену оцінку, зумовлену потребою уникнення тавтології. Їхнє ядро репрезентують утворення «автор + бібліонім»: Багато що споріднюе Котляревського з його великим земляком, котрий ставився до автора «Енеїди» з глибокою пошаною, - маємо на увазі Миколу Васильовича Гоголя (Гончар, 1980: 19); ...не померк реальний образ автора «Енеїди» та «Наталки Полтав$\boldsymbol{\kappa} \boldsymbol{u}$ (Гончар, 1980: 20). Реалізовану ними відносно нейтральну оцінку можуть посилювати атрибутивні модифікатори зі значенням «утривавлення в часі» (безсмертний), «емоційно-психічний стан» (веселий): Два століття живе на світі безсмертний автор «Енеїди» й «Наталки Полтавки» (Гончар, 1980: 18); Коли з волі одного хоробрі душі сподвижників Тараса Бульби після бою возносяться на небо, то десь на півдорозі вони стрічають богів Олімпу в козацьких шатах, що їх веселий автор «Енеїди саме в цей час скидає з неба на землю для участі в земних жичеейських ділах (Гончар, 1980: 19). Наступний розряд щойно розглядуваних перифраз маніфестують конструкції описового характеру «той, хто створив поему + конкретна характеристика головного персонажа «Енеїди»: Той, хто створив образ відважсного козака Енея, $і$ той, хто оспівав Тараса Бульбу, обидва вони в тлумаченні понять обов 'язку й честі завжди знаходять спільну мову (там само). 
В окрему групу вирізнено синтаксичні структури, які є описовими найменуваннями всього, що стосується внутрішнього світу досліджуваного антропоніма. Їхнє призначення «полягає не стільки в номінуванні, скільки в створенні <...> емоційного образу в реципієнта» (Макарець, 2012: 157). Основною базою для конституювання цих перифраз слугує лексема людина: Патріот, людина високої вірності обов'язкові, Котляревський замолоду не раз опинявся у вирі пристрастей своєї доби (Гончар, 1980: 20); Те, про що Шевченко скаже на повен голос, із усією нещадимістю... Котляревський лише зачіпає принагідно, хоча, коли судити з картин пекла в «Енеїді», навряд чи можуть бути сумніви в тому, на чиєму боці були симпатії... людини просвітительських демократичних перетворень (Гончар, 1980: 21); ...ось такого <... веселуна, кепкувальника, людини передових поглядів, нам треба запам'ятати... (Гончар, 1980: 20). Як засвідчують подані приклади, спектр детермінувальних компонентів представлений синтаксичними конструкціями з ідентифікувальною семою 'суспільно значуща оцінка' (вірність обов'язку, просвітительські перетворення, демократичні перетворення, передові погляди). Його розширюють лексичні одиниці, для яких об'єднувальною є сема 'внутрішні якості людини': Все це здається ймовірним, якщо мати на увазі, що для Котляревського, людини гарної, вразливої, героїчна минувшина свого народу не була порожнечею (Гончар, 1980: 22). Розглядуванім перифрази виразніше експлікують суб'єктивну оцінку, передають позитивне авторське ставлення до повідомлюваного.

Вершинним компонентом в аналізованій перифрастичній парадигмі $є$ вторинні номінування з двома детермінованими конституентами - мудрець, в інтенсіоналі якого містяться семи 'людина, що має великий розум, досвід, глибокі знання', 'мислитель, філософ', та син, який експліцитно актуалізує сему 'представник української нації'. Перший іменник сполучається з прикметником веселий, що асоціюється не лише з рисами вдачі письменника, а й із жанром, у якому він працює, та поемою, що представляє цей жанр. Другий іменник вступає в семантико-синтаксичні зв'язки з хоронімом Україна й ад'єктивом достойний, значення якого декодує текстовий фрагмент, що завершує статтю Олеся Гончара: «...люди вміють шанувати тих, хто в минулому, - часто за найтяжчих умов, - віддавав сили розуму й пориви серця праведній справі народу, справі людського поступу. Серед них достойний син України Іван Котляревський» (Гончар, 1980: 27).

3-поміж антропонімних перифраз зафіксовано й ті, які характеризують професійну діяльність Івана Котляревського. Це, зокрема, описові найменування молодий хоробрий офіцер; письменник, близький до народу:...риси ось такого молодого хороброго офіцера < .. > нам треба запам'ятати (Гончар, 1980: 20); ...навряд чи можуть бути сумніви в тому, на чиєму боці були симпатії письменника, близького до народу... (Гончар, 1980: 21). Майстерність автора статті полягає в тому, що він, активно використовуючи перифрази, чітко замотивовує на рівні тексту їхню сутність. Наприклад, участь Івана Котляревського у воєнних баталіях (отже, й еволюцію творення описової структури 3 детермінованим компонентом офіцер) розкриває такий контекст: То бачимо 
його [Івана Котляревського] учасником штурму турецьких фортець, то вже він крокує вулииями Дрездена, - це по тому, як Котляревський з ентузіазмом формував з числа своїх земляків козацький полк для боротьби з наполеонівською навалюю... (Гончар, 1980: 20). Що ж до письменницького фаху, то коментаpi зайві. Життя потвердило ту істину, що Котляревський справді народний майстер слова, письменник-гуманіст, який на себе ... брав відповідальність за долю рідної культури (Гончар, 1980: 22).

Повідомлено в статті через перифрастичне тло і про почесні звання Івана Котляревського: 1821 року вже відомого поета, драматурга, театрального і громадського діяча за рекомендацією Миколи Гнєдича, відомого перекладача Гомерової «Іліади», «було обрано почесним членом "Вольного общества любителей российской словесности” (Гончар, 1980: 23).

3-поміж описових й образно-переносних номінувань бібліонімів найбільше уваги приділено «Енеїді». Крізь призму перифрастики розкрито не лише її авторство, а й значення для духовного поступу українства. Авторство репрезентує вторинна назва голос особистості Котляревського: Написав «Енеїду», звичайно, Котляревський, авторське право належить йому, славетна поема - ие голос його особистості...(Гончар, 1980: 18). Граматичним центром інформативно-оцінних перифраз досліджуваного бібліоніма є іменники голос, перемога, явище, витвір: ...його [Котляревського] поема - це явище вже нової літератури (Гончар, 1980: 23); Це [поема «Енеїда»] був голос життя, перемога мистещького реалізму в літературі...( Гончар, 1980: 23); «Енеїд» витвір воістину дивовижний... (Гончар, 1980: 23); Так бурлескно-травестійна поема стала поемою народною, істинно класичним творінням... (Гончар, 1980: 24). Ядерними компонентами цієї перифрастичної парадигми слід вважати синтаксичні конструкції явище вже нової літератури (Гончар, 1980: 23), істинно класичне творіння (Гончар, 1980: 24). Вони найоб'єктивніше демонструють виняткове значення «Енеїди» в українському літературному процесі, максимально уподібнені в текстуально-значеннєвій співвідносності до вторинних номінувань зачинатель нової украӥнської літератури та перший український класик, які входять до іншого перифрастичного поля. 3 розглядуваними описовими назвами семантично перегукується метафорична структура весняна повінь народної мови із залежною від неї ускладненою однорідними членами підрядною присубстантивно-атрибутивною частиною: ...його поема - ... ие весняна повінь народної мови, що вивільнилася від церковної книжності, від канонів латинських поетик (Гончар, 1980: 23).

В окрему групу вирізнено складну з погляду формально-синтаксичної організації перифразу, що, з одного боку, указує на зв'язок Котляревського з його попередниками, передусім тими, які працювали в бурлескно-травестійному жанрі, а з іншого - промовисто вияскравлює специфіку його ідіостилю: Перед нами не просто жсартівливий переспів античного сюжету, а щось далеко складніше, оригінальніше й химерніше, що змушує своєю мистецькою несподіваністю згадати й Рабле, і Свіфта (Гончар, 1980: 24). У статті наголошено й на такому вельми сутнісному моментові: у«перелицьованій “Енеїді”... від Вергілія нічого, опріч фабули, не лишилося» (Гончар, 1980: 23). 
Поруч із власне авторськими описовими номінуваннями бібліоніма «Енеїда» у статті функціюють інтертекстуальні перифрази: Саме так іï [«Енеїду»] прочитано було декабристами, чий часопис «Соревнователь просвещения и благотворения» назвав «Енеїду» твором, «сповненим дотепності й орихінальності» (там само). Використовуючи їх, автор прагне переконливіше потвердити свою думку, знайти ваговитіші аргументи на користь висловленого.

3 особливою виразністю це продемонстровано в такому контексті 3 інтертекстуальним компонентом і пов'язаними з ним авторськими синонімічними вторинними номінуваннями, що мають складну формально-синтаксичну будову: «Декому з сучасників Котляревського, - до того ж людям доброзичливим у ставленні до нашої культури, - його “Енеїд” видалася підсумком, "пам'ятником мови, що належсла народові колись славному”, мови, яка - так уявлялося тодi, - напевно, “житиме” в одному цьому пам'ятникові. Вийшло ж, що не підсумок, а тільки початок! Не заключний акорд, а тільки пролог, який віщував могутній розвій культури народу в майбутньому, - от чим виявилися творіння веселого й життестійкого генія.» (Гончар, 1980: 26).

Окрему парадигму утворюють описові назви бібліоніма «Наталка Полтавка». У статті ії поіменовано ще одним творінням Котляревського (Гончар, 1980: 24). Функції цих перифраз різноманітні, а саме: 1) указівка на хронологічне місце п'єси Івана Котляревського в історії виникнення й розвитку національного театру: «Наталка Полтавка» <...> стала його [нашого національного театру] вранішньою зорею...( Гончар, 1980: 26); ...молодь і старші випробовують себе в ролях цієї народної першоп'єси (Гончар, 1980: 26). Значення не менше, а в чомусь, може, навіть $і$ більше, ніж вихід «Енеїди», мало для нашої культури ще одне творіння Котляревського - його знаменита «Наталка Полтавка», ия праматір украӥнського театру (Гончар, 1980: 24). Остання перифраза - інтертекстуальна описова структура, авторство якої належить Іванові Карпенку-Карому: 2) мистецька вартість, якість п'єси: «Наталка Полтавка» <...> лишилася найкращою школою для великих майстрів сцени (Гончар, 1980: 26); У «Наталці Полтавці», в цьому емоційно насиченому, рідкісно гармонійному творінні, чи не найбільше відчувається особистість авто$p a$, його натура, словесна й поетична, розум тонкий та возвишений, як тоді казали (Гончар, 1980: 25); 3) оцінка твору народом: «Наталка Полтавка», ия найулюбленіша п'єса українського народу, зросла на грунті народної творчості, вона багато що ввібрала з українського фольклору (Гончар, 1980: 25).

За «Енеїдою», «Наталкою Полтавкою», «Москалем-чарівником» у статті закріплено назву творіння веселого й життєдайного генія (Гончар, 1980: 26). Виділена перифраза позначає два референти - бібліонім та патронім. Описову структуру веселий $i$ життєдайний геній можна вважати вершинним компонентом перифрастичної парадигми «внутрішні якості письменника». Родовою перифразою до видових вторинних номінувань проаналізованих вище бібліонімів є синтаксична конструкція самобутне слово Котляревського: «Передова <...> громадськість доброзичливо зустріла самобутнє 
слово Котляревського [поему “Енеїда”, п’єси “Наталка Полтавка”, “Москальчарівник”], і це багато про що нам промовляє» (Гончар, 1980: 19).

У статті згадано таких персонажів творів Івана Котляревського, як Еней, Еол, Юнона, Наталка, Петро. Одного з них - возного Тетерваковського - представлено в перифрастичній версії - перший крючкотворець-бюрократ: У п'єсі Котляревського вперше вийшли на кін <... > живі народні типи; між чесними трудівниками з'являється вже й образ першого крючкотвориябюрократа, що ним $є$ Возний...(Гончар, 1980: 25). Причину цього вторинного номінування розкриває сам Олесь Гончар: у мові судового чиновника Тетерваковського «відбито реальне життя» (там само) - тодішнє і, на превеликий жаль, якоюсь мірою й натеперішнє.

\section{Висновки}

Отже, важливим художньо насиченим складником образності літературознавчої статті Олеся Гончара «Безсмертний полтавець» $є$ перифрази. Вони зрідка виконують чисто описову, а не регулярно образно-описову функцію. За допомогою вторинних номінувань автор різнобічно характеризує постать Івана Котляревського в історії української літератури й культури (антропонім-перифраз) і всеукраїнське та світове значення його творчого доробку (бібліоніми-перифрази).

\section{ЛIТЕРАТУРА}

1. Гончар О. Безсмертний полтавець. Письменницькі роздуми : літературно-критичні статті. Київ, 1980. С. 18-27. 2. Макарець Ю. Перифразові номінації в українському публіцистичному дискурсі: монографія. Київ, 2012. 205 с.

\section{REFERENCES}

1. Honchar, O. Bezsmertnyi poltavets [The Immortal Poltavite]. Pysmennytski rozdumy: literaturno-krytychni statti [Writers' reflections: articles on literary criticism]. K., 1980. - S. 1827 [in Ukrainian]. 2. Makarets, Yu. Peryfrazovi nominatsii v ukrainskomu publitsystychnomu dyskurs: monohrafiia [Periphrasis nominationin Ukrainian publicistic discourse: monograph]. - K., 2012. - 205 s. [in Ukrainian].

Степаненко Микола Іванович - доктор філологічних наук, професор, ректор Полтавського національного педагогічного університету імені В. Г. Короленка; вул. Остроградського, 2, м. Полтава, 36000, Україна.

E-mail:myk_ivan@ukr.net

http://orcid.org/0000-0002-6727-1265

Stepanenko Mykola Ivanovych - doctor of philology, professor, Head of the V. G. Korolenko Poltava National Pedagogical University. Ostrogradskogo Str., 2, Poltava, 36000, Ukraine. 